\title{
TRANSISI PENGGUNAAN BAHASA ASING DI ABAD 21; SEBUAH KECENDERUNGAN GLOBAL
}

\author{
Noverita Wahyuningsih \\ Dosen Luar Biasa Jurusan Bahasa dan Sastra Inggris \\ Fakultas Humaniora dan Budaya, Universitas Islam Negeri (UIN) Malang. \\ Jalan Gajayana No. 50 Telepon (0341) 551354, Faksimile (0341) 572533 Malang 65144
}

\begin{abstract}
Up to the end of the twentieth century, Arabic and English have played an important role as the media for communication all over the world. Both languages are significantly used in not only national but also global scopes. Millions of people in the world today use either passive or active Arabic and/or English in their daily lives. The question is,' will the global community in the $21^{\text {st }}$ century still put these international languages in a position as important as it is today?' Trends in the use of languages in the world can be viewed from several different aspects, among which are the economic strength of a language and the demography of language users. Although so far there has been no fixed agreement on the criteria of a language to be called as "the world language" yet, there is a tendency that by mid $21^{\text {st }}$ century there will be trends in the world's language domination and hierarchy. The trends will also involve the global use of Arabic and English. The two languages are predicted to still have an essential position as the world's major languages and therefore will be used globally. The use of Arabic and English is strongly predicted to undergo a transition in a positive way. In addition to that, it is not impossible that by mid $21^{\text {st }}$ century, there will be a tendency of bilingual education (using foreign languages in presenting non-linguistic school subjects) spreading in the world's urban areas, including those areas in Indonesia.
\end{abstract}

\section{Key words}

Transition, Global Community, Arabic, English 


\section{Pendahuluan}

Dalam era globalisasi kini, peran bahasa asing yang semakin penting di Indonesia tidak dapat dipungkiri lagi; dan selama ini, bahasa asing (termasuk bahasa Inggris) telah dipergunakan di negara kita untuk berbagai macam tujuan yang berbeda. Sadtono (1996:18) memprediksikan bahwa terlepas dari upaya yang dilakukan Pemerintah untuk memurnikan bahasa Indonesia dari pengaruh bahasa asing, ujaran-ujaran dalam bahasa Inggris masih akan terus merembes ke dalam bahasa Indonesia. Rembesan semacam itu tidak akan dapat dihindari lagi.

Universitas Islam Negeri (UIN) Malang yang merupakan perguruan tinggi negeri berwawasan internasional, juga menyadari peran penting bahasa asing dalam masa yang semakin global kini, ketika teknologi komunikasi dan transportasi telah mempermudah manusia untuk berinteraksi dan sekaligus menjadikan jarak dan waktu bukan lagi sebagai kendala dalam lingkup dunia.

Dengan ribuan mahasiswa yang kini menempuh studi di universitas ini, UIN Malang mengembangkan struktur keilmuan yang juga memperhatikan kecenderungan global tersebut. Struktur keilmuan yang dikembangkan UIN Malang menggunakan metafor sebuah pohon yang kukuh dan rindang bagi para peserta didiknya. Pohon yang berakar kuat menghunjam ke bumi juga akan melahirkan batang yang kukuh pula. Akar yang kukuh tersebut digunakan untuk menggambarkan kemampuan berbahasa asing, yakni bahasa Arab dan bahasa Inggris, serta logika dan filsafat, ilmu-ilmu alam dan ilmu-ilmu sosial. Kedua bahasa asing tersebut - bahasa Arab dan bahasa Inggris dipandang sebagai dua bahasa asing yang harus dikuasai oleh setiap mahasiswa UIN Malang (UIIS Malang, 2002:14-15). Bahasa Arab digunakan sebagai piranti mendalami ilmu-ilmu yang bersumber dari al-Qur'an dan hadits Nabi serta kitab-kitab berbahasa Arab, sedangkan penggunaan bahasa Inggris dipandang penting sebagai bahasa ilmu pengetahuan dan teknologi dan bahasa pergaulan internasional. 
Namun sebenarnya sampai berapa lamakah penggunaan bahasa Inggris dan bahasa Arab sebagai bahasa besar di dunia dapat bertahan? Akankah dunia global pada abad 21 nanti tetap menempatkan bahasabahasa asing yang kini dianggap sebagai bahasa internasional pada posisi yang sama pentingnya dengan sekarang? Artikel ini hendak membahas tentang penggunaan bahasa asing saat ini di dunia serta kecenderungannya hingga pertengahan abad ke-21 nanti yang bukan saja mencakup skala nasional di Indonesia melainkan juga pada skala global di dunia internasional.

\section{Bahasa Dunia Abad 20}

Hingga tahun 1997, diperkirakan bahwa di seluruh dunia terdapat tidak kurang dari 6000 bahasa secara keseluruhan (Graddol, 2000:13). Secara hirarkis, ribuan bahasa yang terdapat di seluruh dunia tersebut dapat dibedakan menjadi empat kelompok besar menurut wilayah geografis penggunaannya dengan strata vertikal. Kelompok dengan skala terkecil adalah kelompok bahasa daerah atau local languages. Kelompok kedua adalah bahasa nasional, yakni bahasa yang digunakan dalam suatu wilayah negara. Kelompok dengan strata yang setingkat lebih tinggi dari bahasa nasional adalah kelompok bahasa regional. Kemudian, yang berada di puncak piramida hirarkis bahasa adalah bahasa besar atau bahasa utama yang digunakan untuk berkomunikasi antar negara.

Hingga akhir abad ke-20 yang lalu, bahasa Arab menempati posisi penting sebagai salah satu di antara tujuh bahasa regional dalam hirarkis bahasa-bahasa di seluruh dunia. Hal ini menunjukkan bahwa selain digunakan sebagai bahasa nasional di Arab Saudi, bahasa Arab juga digunakan sebagai bahasa regional pada beberapa negara yang berada dalam satu wilayah (region) yang berdekatan. Sebagai bahasa regional, bahasa Arab berada pada tingkatan kedua tertinggi dari puncak hirarkis semua bahasa dunia yang jumlahnya mencapai ribuan bahasa. 
Sebagai bahasa regional, bahasa Arab digunakan sebagai bahasa nasional di Afrika Utara, jazirah Arab, Siria, Lebanon, Yordania, dan Irak. Selain di wilayah tersebut, bahasa Arab juga digunakan oleh kaum Arab di Israel, serta di beberapa wilayah sekitar gurun Sahara di Afrika, Amerika Utara dan Amerika Selatan, serta di Uni Soviet wilayah Asia Tengah. Menurut Grimes (dalam Graddol 2000:8) Bahasa Arab saat ini merupakan salah satu bahasa utama di dunia (major world languages) yang menempati urutan kelima tertinggi menurut jumlah penutur asli yang menggunakannya sebagai bahasa pertama (first language). Di seluruh dunia, terdapat setidaknya sekitar 202 juta orang penutur asli bahasa Arab yang menggunakannya sebagai first language mereka. Ini berarti bahasa Arab dipandang sebagai bahasa utama di dunia yang patut dipertimbangkan sebagai bahasa internasional yang relatif dominan. Di Indonesia, bahasa Arab diajarkan di berbagai lembaga pendidikan, baik lembaga pendidikan formal maupun lembaga pendidikan non-formal.

Selain bahasa Arab, bahasa yang dipandang sebagai bahasa asing utama di Indonesia adalah bahasa Inggris. Posisi bahasa Inggris hingga akhir abad keduapuluh adalah sebagai bahasa besar atau bahasa utama di dunia. Tidak kurang dari 372 juta orang di dunia menggunakan bahasa Inggris sebagai bahasa pertama saat ini. Menurut Grimes (1996), sebanyak 375 juta orang menggunakan bahasa Inggris sebagai bahasa kedua, dan 750 juta jiwa menggunakannya sebagai bahasa asing (foreign language).

Di seluruh dunia, terdapat lebih dari 30 negara dan teritori yang menggunakan bahasa Inggris sebagai bahasa pertama. Dalam hirarkis bahasa-bahasa dunia saat ini, terdapat dua bahasa di dunia yang berada dalam strata tertinggi piramida hirarkis bahasa tersebut. Pada akhir abad ke-20, bahasa Inggris menempati puncak piramida hirarkis bahasa sebagai bahasa terbesar di dunia, selain bahasa Perancis.

Menurut Saukah (2003:1-2) pada tahun 1997, terdapat sembilan belas negara yang mengalami transisi penggunaan bahasa Inggris dari sebagai bahasa asing menjadi bahasa kedua. Meskipun Indonesia tidak 
termasuk dalam daftar kesembilan belas negara tersebut, menurut Graddol (2002:10-11), Sudan - negara partner UIIS yang saat ini menggunakan bahasa Arab sebagai bahasa pertama- serta Uni Emirat Arab adalah dua di antara negara-negara yang sedang mengalami transisi penggunaan bahasa Inggris ke arah bahasa kedua (English as a second language), bukan lagi bahasa asing (foreign language). Selain itu, Saukah juga menyebutkan bahwa jumlah buku yang diterbitkan di dunia selama ini sebagian besar (mencapai 28\%) diterbitkan dalam bahasa Inggris.

Paparan tersebut menunjukkan betapa kedua bahasa asing tersebut - yakni bahasa Arab dan bahasa Inggris - merupakan bahasa penting yang dipergunakan bukan saja dalam lingkup nasional melainkan dalam lingkup global. Kedua bahasa tersebut digunakan secara aktif maupun pasif oleh jutaan orang di belahan bumi ini, setidaknya hingga penghujung abad ke-20 yang lalu.

\section{Transisi Bahasa dalam Proses Globalisasi}

Pembicaraan mengenai bahasa tidak akan dapat dilepaskan dari topik budaya dan peradaban. Perkembangan peradaban, sebagaimana dikemukakan oleh Rahardjo (2002:175-176), diprasyarati oleh bahasa baik bahasa pertama, bahasa kedua, maupun bahasa asing. Rahardjo mengemukakan bahwa bahasa, dalam konteks tertentu, merupakan salah satu prasyarat kultural yang paling penting. Bahasa harus menjadi piranti utama bagi seseorang atau kolektiva yang ingin ikut ambil bagian dalam pengembangan peradaban.

Globalisasi merupakan salah satu indikator berlangsungnya pengembangan peradaban di mana manusia serta peristiwa-peristiwa kultural yang merupakan akibat dari interaksi antar manusia dipandang sebagai hal yang mengalami proses masuk ke lingkup dunia secara keseluruhan. Dalam proses globalisasi, bahasa -yang memiliki kecenderungan untuk mengalami perubahan (change) dan pergantian (shift) - juga cenderung bersifat dinamis. Karenanya, penggunaan bahasa di dunia global juga menampakkan adanya dinamika tersebut. 
Salah satunya adalah dengan adanya kecenderungan transisi penggunaan bahasa di dunia.

Kecenderungan-kecenderungan penggunaan bahasa di dunia yang terjadi dalam era yang semakin global ini dapat ditinjau dari beberapa aspek, di antaranya adalah aspek demografis pengguna bahasa serta aspek kekuatan ekonomi bahasa.

\section{Pertumbuhan Penduduk dan Penggunaan Bahasa}

Rahardjo (2002:245) memperkirakan bahwa saat ini $80 \%$ penduduk negara-negara maju tinggal di wilayah perkotaan dan hanya sebagian kecil saja yang tinggal di desa. Bahkan, pada tahun 2023 nanti diperkirakan proporsi tersebut meningkat menjadi 100\%. Ini berarti, berdasarkan perkiraan tersebut, menjelang seperempat abad 21 kelak, semua penduduk dunia akan tinggal wilayah urban, tidak ada lagi yang tinggal di desa!

Selain itu, wilayah perkotaan juga diperkirakan akan semakin meningkat baik dari segi geografis maupun demografis. Artinya, area urban akan semakin meluas sekaligus jumlah penduduk di wilayah tersebut akan semakin meningkat pula jumlahnya. Pada tahun 2000 yang lalu, ibukota negara Indonesia, Jakarta, masuk dalam kategori sepuluh besar kota terbesar di dunia menurut jumlah penduduk yang menghuninya. Graddol (2002:27) menyebutkan bahwa terdapat sekitar 13,7 juta penduduk Jakarta pada tahun 2000, dan diperkirakan jumlah ini akan berlipat dalam kurun lima dekade mendatang. Mengingat Jakarta adalah daerah urban terbesar di Indonesia, maka dapatlah dikatakan bahwa penggunaan bahasa asing di Jakarta pada lima dekade mendatang juga akan berlipat sebagaimana meningkatnya angka demografis di kota ini.

Kecenderungan ke arah urbanisasi kehidupan sangat besar, yang selanjutnya akan menyusun ekosistem manusia di abad 21 ini menjadi sangat urban, baik secara fisik maupun sosial. Padahal, di kota atau daerah urban kecenderungan untuk menggunakan bahasa asing lazimnya lebih besar daripada di desa. Dengan demikian, ekosistem 
manusia urban di abad 21 pun akan cenderung meningkatkan penggunaan bahasa asing dalam berinteraksi.

Persatuan Bangsa-Bangsa memprediksikan bahwa populasi penduduk dunia pada pertengahan abad ke-21 kelak, yakni tahun 2150, akan mencapai jumlah sebesar 11,54 milyar. Graddol (2000:26-27) memprediksikan bahwa seiring dengan adanya perbedaan laju peningkatan jumlah penduduk dunia di berbagai negara, penggunaan bahasa di dunia pun akan mengalami perbedaan jumlah penuturnya. Dengan laju pertumbuhan penduduk yang sangat pesat, Cina yang memiliki jumlah penduduk tertinggi diperkirakan akan menduduki peringkat tertinggi dalam estimasi jumlah penutur bahasa pertama (first-language speakers), yakni sebanyak 1,384 milyar.

Sementara itu, bahasa Inggris menduduki peringkat ketiga dengan jumlah penutur bahasa pertama (first-language speakers) diperkirakan sebanyak 508 juta jiwa pada pertengahan abad 21 kelak. Lebih lanjut, Graddol menyebutkan bahwa angka demografis penutur bahasa Arab sebagai bahasa pertama (first-language speakers) pada pertengahan abad 21 nanti adalah sekitar 482 juta. Ini berarti, meskipun memiliki laju peningkatan jumlah penutur asli yang relatif lebih tinggi dibanding dengan laju peningkatan jumlah penutur asli bahasa Inggris, bahasa Arab diperkirakan akan menduduki peringkat kelima (sesudah bahasa Cina, Hindi/Urdu, Inggris, dan Spanyol) dalam estimasi jumlah demografis penutur aslinya pada tahun 2050 yang akan datang.

Tabel 1 menyajikan perkiraan estimasi jumlah penutur asli (dalam juta jiwa) delapan bahasa utama di dunia sebagai bahasa pertama (first-language speakers) pada pertengahan abad ke-21 nanti, menurut Graddol (2002:26-27). 


\section{Estimasi Jumlah Penutur Asli}

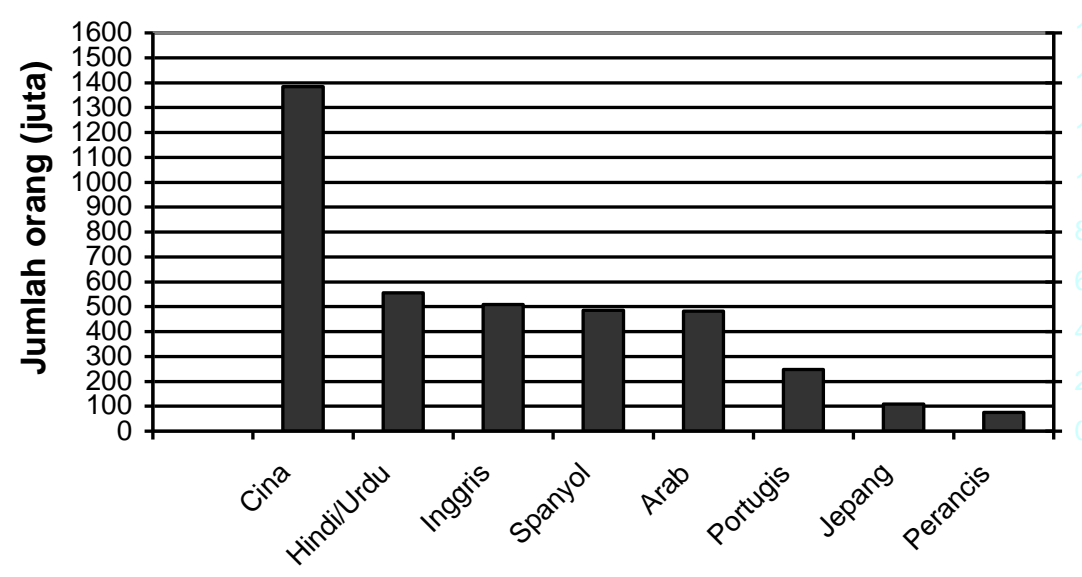

Bahasa

\section{Kekuatan Ekonomi Bahasa (The Economic Strength of A Language).}

Ammon (dalam Graddol, 2002:28) berpendapat bahwa suatu bahasa yang digunakan oleh sebuah komunitas yang secara ekonomis sangat kuat akan sangat menarik untuk dipelajari karena alasan potensi bisnis. The British Council, sebuah organisasi yang bertujuan mempromosikan Inggris maupun bahasa Inggris, mengestimasi kekuatan ekonomi dari suatu bahasa dengan pendekatan tersendiri untuk memperoleh indeks kekuatan ekonomi suatu bahasa yang disebut Gross Language Product (GLP). Nilai GLP ditaksir dengan cara menjumlahkan kekayaan ekonomi dari negara negara yang warga negaranya menggunakan bahasa tersebut sebagai bahasa pertama.

Hingga akhir tahun 1980-an, Bahasa Arab diestimasi memiliki kekuatan ekonomi pada peringkat ke-8 dari seluruh bahasa di dunia (Ammon, dalam Graddol, 2002) dengan nilai Gross Language Product (GLP) sebesar 359 milyar dolar. Sementara itu, bahasa Inggris diestimasi memiliki kekuatan ekonomi senilai 4.271 milyar dolar yang berarti 
peringkat pertama dalam urutan kekuatan ekonomi bahasa internasional hingga akhir tahun 1990-an.

Dalam dunia ekonomi, terdapat tren bahwa seiring dengan perkembangan perekonomian suatu negara, biasanya sektor ekonomi cenderung bergeser dari sektor primer (seperti sumberdaya dan pertanian) maupun sektor sekunder (yakni industri dan penggunaan mesin) menuju ke arah sektor tersier, yakni industri jasa atau service industries.

\section{Tren Bahasa Dunia pada Abad 21}

Meskipun hingga saat ini belum ada jawab atas pertanyaan mengenai hal-hal apa yang dapat membuat sebuah bahasa dikatakan sebagai bahasa 'dunia', namun kiranya beberapa indikator dapat dijadikan acuan untuk menyatakan pengaruh suatu bahasa terhadap dunia global.

Graddol (2000:26-27) memproyeksikan bahwa kelak pada tahun 2050, duabelas bahasa di dunia yang menempati urutan teratas menurut jumlah penutur aslinya adalah berturut-turut: bahasa Cina, Hindi/Urdu, Inggris, Spanyol, Arab, Portugis, Bengali, Rusia, Jepang Jerman, Melayu, dan Perancis. Pada pertengahan abad 21 nanti, Bahasa Arab diperkirakan akan menduduki peringkat kelima dominansi bahasa di dunia menurut jumlah penutur aslinya, yakni tidak kurang dari 482 juta orang.

Bahasa Arab diprediksikan akan mengalami pergeseran vertikal secara positif dalam hirarkis bahasa dunia. Bila hingga akhir abad ke 20 ini bahasa Arab menempati posisi sebagai bahasa regional (yang artinya pada tingkatan kedua dari puncak piramida hirarkis bahasa), maka di abad mendatang bahasa Arab diprediksikan akan lebih penting penggunaannya. Pada tahun 2050, diperkirakan bahasa Arab akan menempati lapisan teratas dalam piramida hirarki bahasa-bahasa dunia, bersama-sama dengan empat bahasa lainnya yaitu: bahasa Cina (di urutan pertama), bahasa Hindi/Urdu, bahasa Inggris, serta bahasa Spanyol. 
Di samping itu, bahasa Arab diproyeksikan masih akan menduduki urutan teratas dalam hirarkis bahasa regional di dunia, tertinggi di antara lima bahasa regional lainnya, termasuk bahasa Inggris yang berada di urutan keempat bahasa regional.

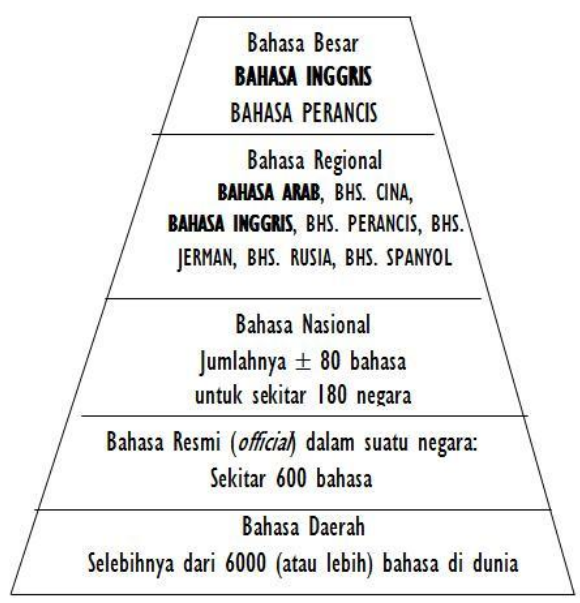

Th. 1997

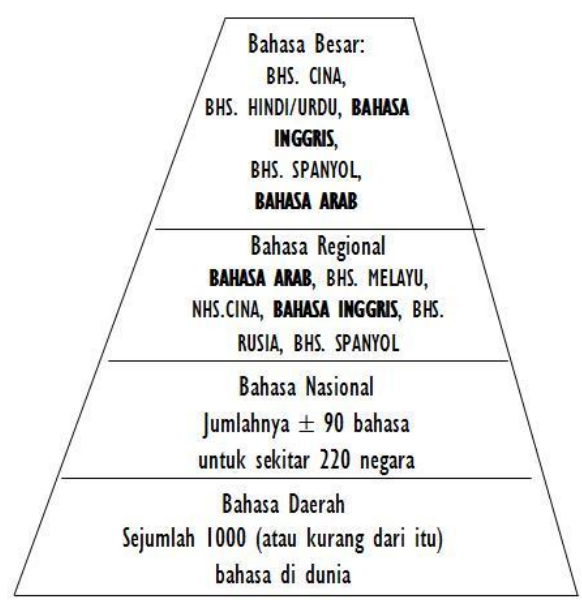

Th. 2050

Gambar 1. Hirarkis Bahasa-Bahasa Dunia pada Abad 20 dan Prediksinya pada Abad 21 (diadaptasi dari Graddol, 2000)

Sementara itu, bahasa Inggris yang pada abad 20 yang lalu banyak berperan sebagai bahasa dominan di antara ribuan bahasa di dunia, pada tahun 2050 kelak diproyeksikan akan menduduki peringkat ketiga dalam dominansi bahasa di dunia menurut jumlah penutur aslinya, yakni tidak kurang dari 508 juta orang.

Bahasa Inggris sebagai salah satu bahasa asing di Indonesia digunakan untuk beragam ranah yang berbeda dalam interaksi manusia di dunia. Graddol (2000:8) menyebutkan setidaknya terdapat dua belas ranah utama penggunaan bahasa Inggris secara internasional (major international domains). Keduabelas ranah tersebut secara berturut-turut adalah dalam: (1) bahasa komunikasi untuk organisasi-organisasi internasional serta untuk konferensi-konferensi tingkat internasional, (2) 
publikasi ilmiah, (3) perbankan, perdagangan, dan urusan ekonomi internasional, (4) dunia periklanan (advertising) untuk produk-produk bermerek global, (5) produk-produk audio-visual untuk pengenalan budaya, seperti film, televisi, serta musik populer, (6) pariwisata internasional, (7) pendidikan tinggi (tertiary education), (8) keamanan internasional, misalnya komunikasi udara dan komunikasi di laut, (9) hukum internasional, (10) bahasa perantara dalam penerjemahan, (11) transfer teknologi, serta (12) komunikasi melalui internet.

Dengan demikian dapat dikatakan bahwa tampaknya akan terjadi fenomena dalam penggunaan bahasa di dunia berupa transisi kecenderungan penggunaan bahasa oleh masyarakat global, dan kecenderungan tersebut juga menyangkut penggunaan bahasa Arab dan bahasa Inggris: dua bahasa asing yang hingga akhir abad keduapuluh merupakan bahasa asing utama yang diajarkan di Indonesia.

\section{Penutup}

Meskipun belum terdapat simpulan yang tegas mengenai kriteria apa yang dapat digunakan untuk menyatakan bahwa suatu bahasa dapat disebut sebagai "bahasa dunia", namun setidaknya ada beberapa hal yang dapat disimpulkan dari fakta dan informasi yang diperoleh hingga akhir abad ke-20 masehi.

Pertama, seiring dengan proses globalisasi terutama di bidang informasi dan komunikasi, pada abad ke-21 akan terjadi kecenderungan transisi dominasi dan hirarkis bahasa di dunia. Fenomena ini diperkirakan juga akan terjadi pada dua bahasa asing utama yang diajarkan di Indonesia, yakni bahasa Inggris dan bahasa Arab.

Dapat diprediksikan bahwa terkait dengan beberapa fenomena transisi penggunaan bahasa di dunia yang akan berlangsung hingga setidaknya lima dekade mendatang, bahasa Inggris dan bahasa Arab masih akan menempati posisi sebagai bahasa-bahasa utama yang digunakan oleh sebagian besar penduduk dunia, bahkan penggunaan 
kedua bahasa tersebut cenderung akan mengalami peningkatan secara positif.

Kedua, tidak mustahil bahwa akan terjadi kecenderungan bilingual education atau pendidikan dwibahasa, yang merupakan pola pendidikan formal yang menggunakan bahasa asing untuk mengajarkan suatu bidang studi inti (non kebahasaan), terutama di daerah perkotaan. Pada sekitar tahun 2050 kelak, dapat diprediksikan bahwa seiring dengan semakin tingginya urgensi penggunaan bahasa yang dapat menjembatani komunikasi antar negara dalam berbagai aspek dengan lingkup global, penguasaan bahasa internasional pun akan dirasakan sebagai kebutuhan. Karenanya, mungkin saja bahwa kelak bahasa Arab dan bahasa Inggris —yang dipandang sebagai dua di antara bahasa-bahasa utama di dunia internasional - akan dirasa perlu untuk digunakan sebagai bahasa pengantar dalam pembelajaran berbagai bidang studi inti dalam pendidikan formal di sekolah-sekolah di Indonesia.

Sebagai penutup, kiranya tidak perlu disangsikan lagi bahwa dua bahasa asing yakni bahasa Arab dan bahasa Inggris yang saat ini dipandang sebagai bahasa utama dalam komunikasi internasional tetap akan dianggap sebagai bahasa penting di dunia dalam jangka waktu yang relatif lama hingga pertengahan abad keduapuluh satu nanti. Fenomena transisi penggunaan bahasa hingga pertengahan abad ke-21 nanti menunjukkan kecenderungan nilai penting kedua bahasa tersebut yang bukan saja mencakup skala nasional di Indonesia, melainkan juga pada skala global di dunia internasional. $\square$ 


\section{DAFTAR PUSTAKA}

Graddol, D. 2000. The Future of English?. London: British Council.

Grimes, B.F. (Ed.). 1996. Ethnologue: Languages of the World. Dallas: Summer Institute of Linguistics.

Rahardjo, M. 2002. Relung-Relung Bahasa: Bahasa dalam Wacana Politik Indonesia Kontemporer. Yogyakarta: Aditya Media.

Sadtono, E. (Ed.). 1996. The Development of TEFL in Indonesia. Malang: Penerbit IKIP Malang.

Saukah, A. 2003, 3 Maret. Pengajaran Bahasa Inggris di Indonesia: Tinjauan terhadap Unjuk Kerja Pembelajar serta Upaya Peningkatannya. Pidato Pengukuhan Guru Besar. Malang: Universitas Negeri Malang.

UIIS Malang. 2002. Tarbiyatu Ulil al-Albâb:Dzikr, Fikr, dan Amal Shaleh. Konsep Pendidikan Universitas Islam Persahabatan Indonesia-Sudan (UIIS Malang). Malang: UIIS Malang. 